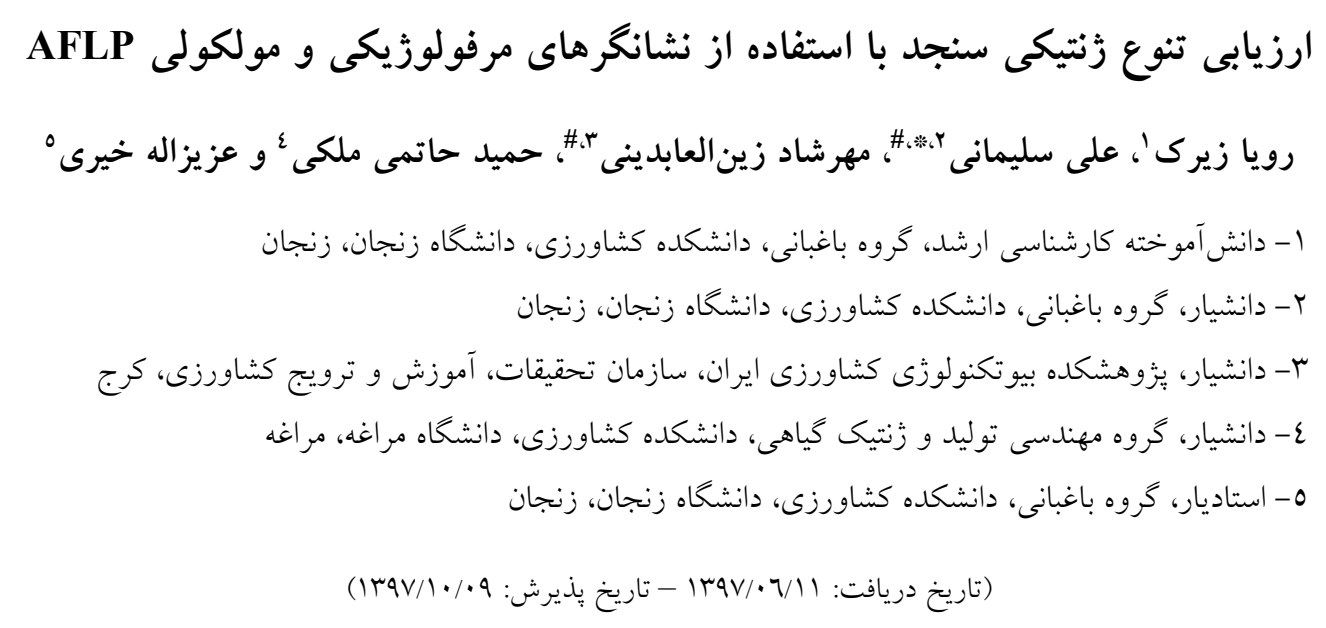

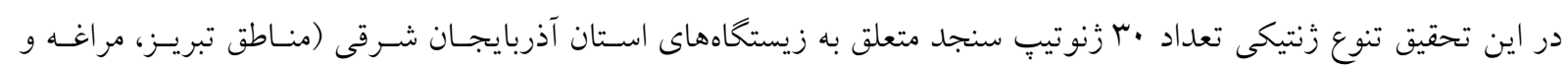

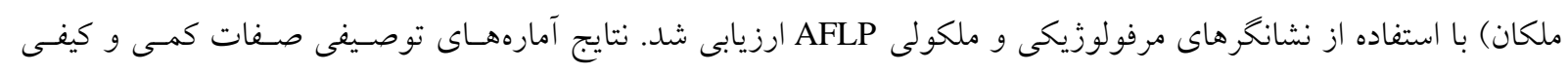

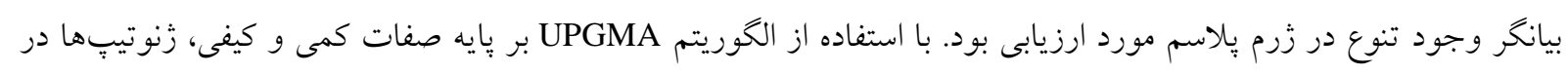

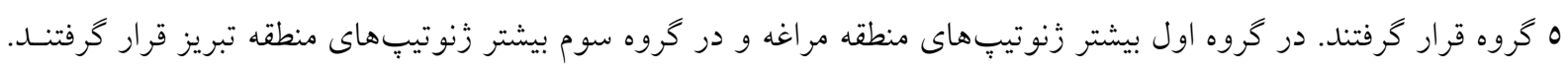

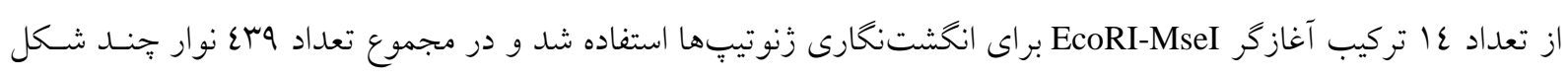

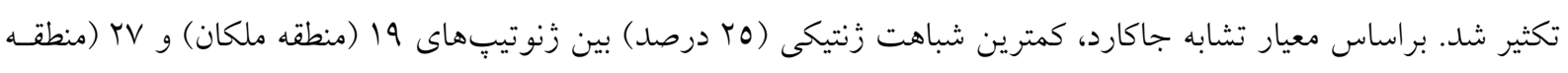

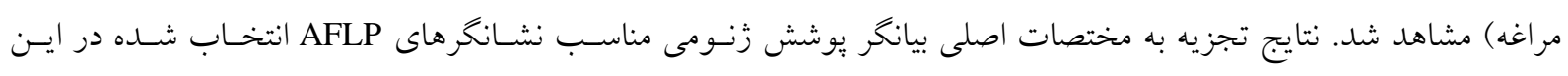

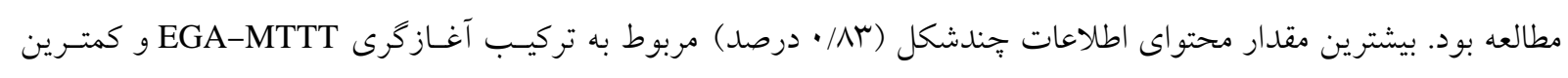

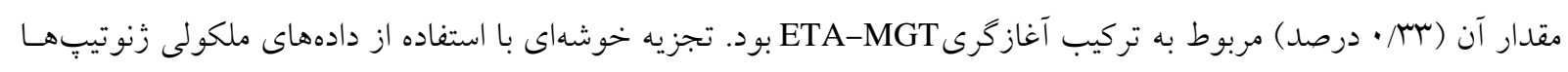

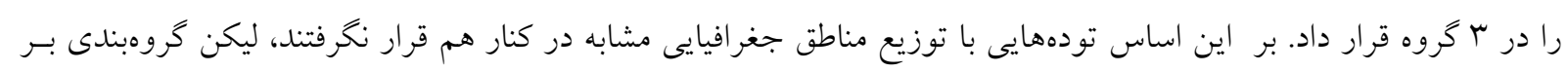

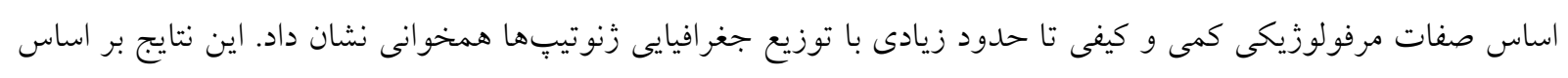

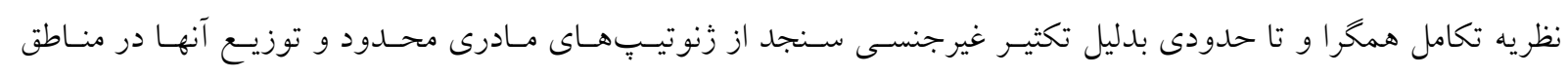
جغرافيايى مورد مطالعه، قابل تفسير مىباشد.

واز كان كليدى: تنوع زنتيكى، سنجد، صفات كمى، AFLP

asoleimani@znu.ac.ir : نويسنده مسئول، آدرس بست الكترونيكى * "اين نويسند انان مشاركت يكسانى در اين مقاله دارند. 
زنتيكى، كزينش زنوتيبها، تهيه نقشههاى زنتيكى، تعيسين مقدمه - - مق

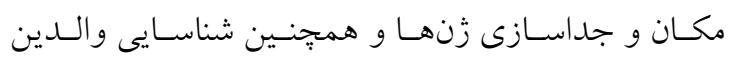

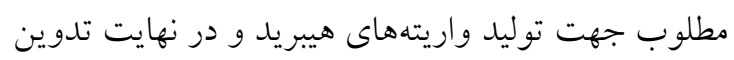

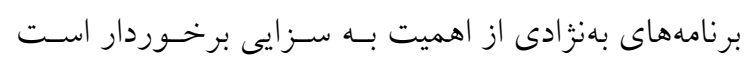

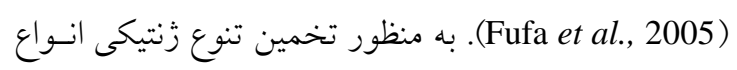

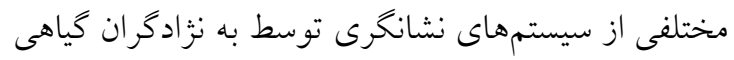

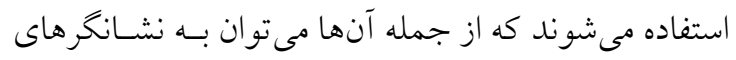

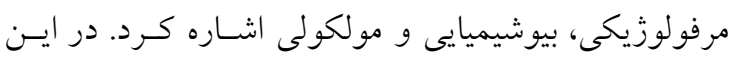

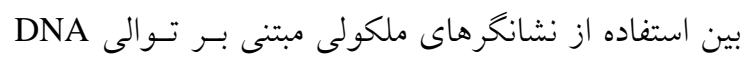

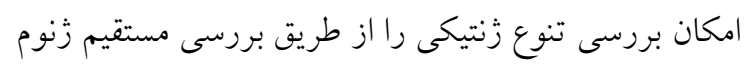

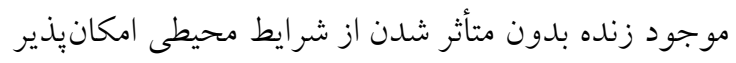

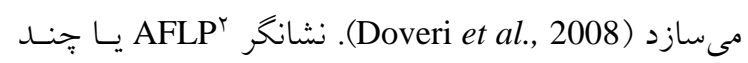

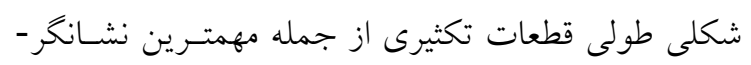

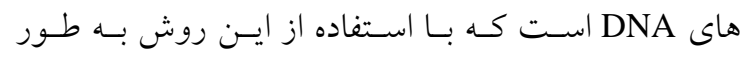

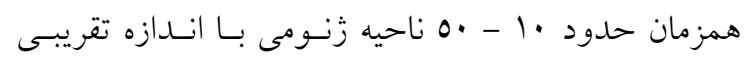

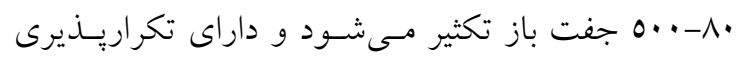

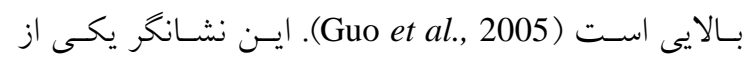
انواع نشانكرهاى مبتنى بر PCR است كه تركيبى از از

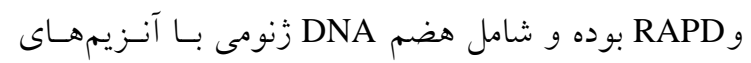

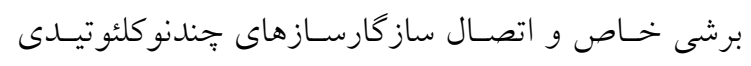

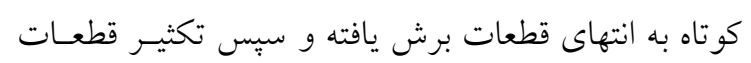

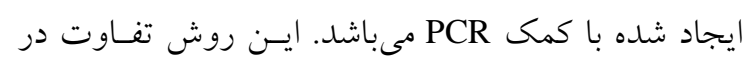

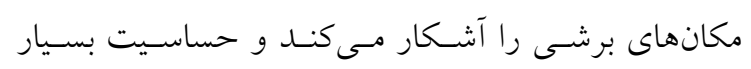

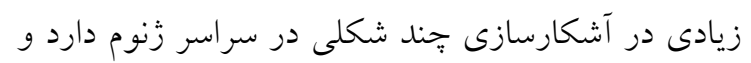

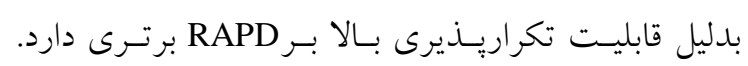

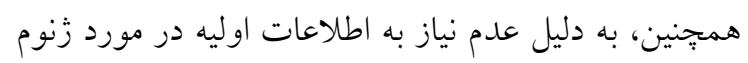

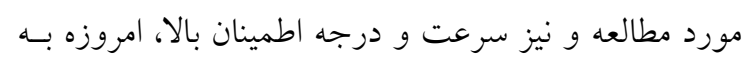
طور وسيعى براى تهيه نشانخرهاى خند شكل استفاده مى شود (Vos et al., 1995).

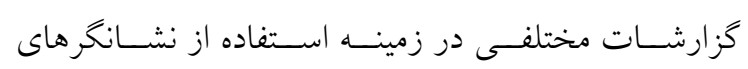
مرفولوزيكى و زنتيكى در ارزيابى زرميلاسم سنجد وجود زئه

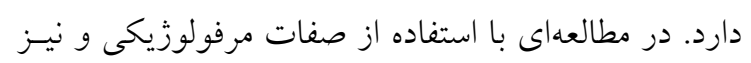

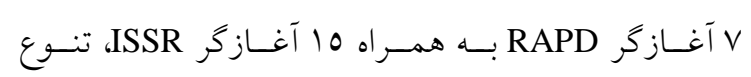

Elaeagnus angustifolia L. درخت سنجد با نام علمى

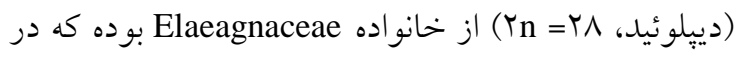

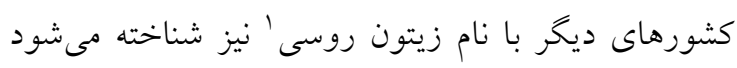
(Arohonka and Rousi, 1980) حدود كونه مختلف و ل ل Shepherdia و در سراسر Hippophae Elaeagnus جهان وجود دارند. سنجد در نواحى سرد و معتدل رشد

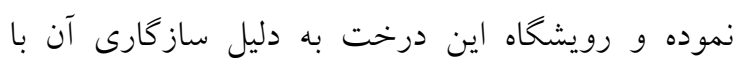
محيطهاى مختلف در اغلب مناطق از جمله آمريكاى

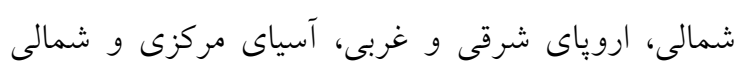

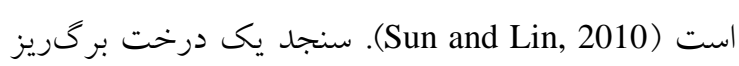

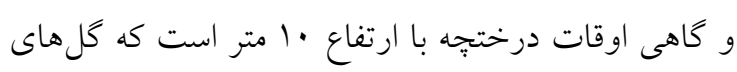

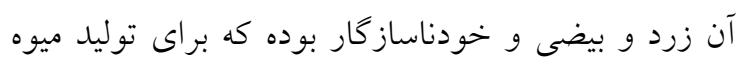

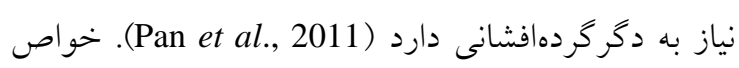

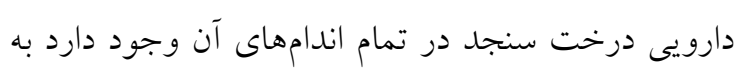

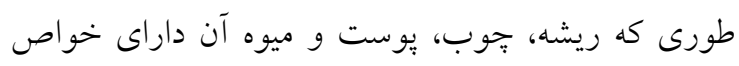

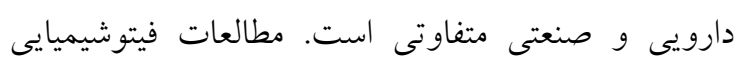
عصاره ميوه و كل سنجد نشان دهنده حضور مواد موثره-

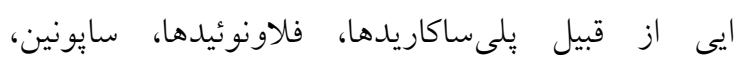
كارتنوئيدها و انواع مختلف تانن مياشد ( 2016). تركيبات استرى و اسيدهاى آروماتيك تركيبات اصلى در عصاره گل اين گياه مىباشد. گياه سنجد همجِين نقش بسيار مهمى در حفظ اكوسيستم طبيعت به دئ

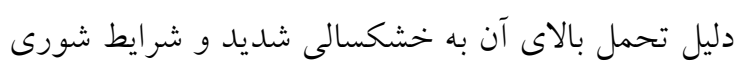

بالاو قليايت خاك ايفا مى كند (Asadiar et al., 2012). تنوع زنتيكى از ملزومات بهنزادى كياهى است كه از تكامل

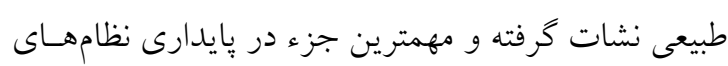

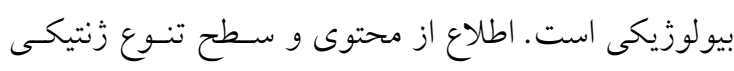

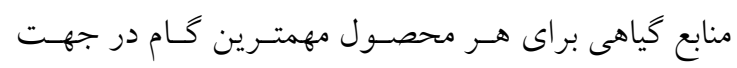

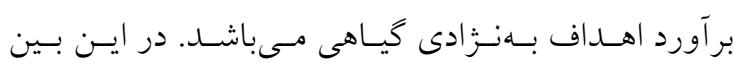

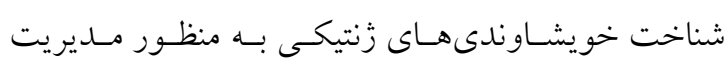

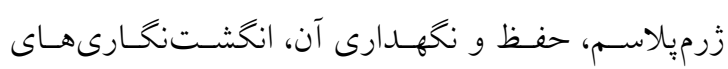




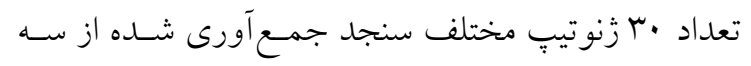

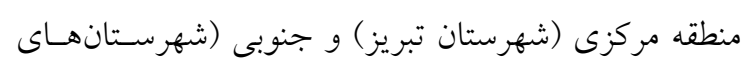

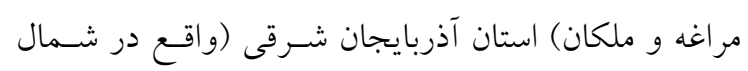
غرب كشور ايران) مىباشند (جدول (1).

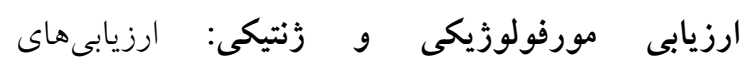
مورفولوزيكى با استفاده از توصيف كرهاى مربوط به كياه

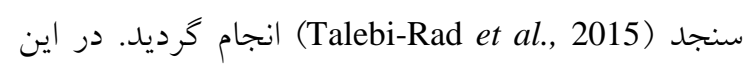
يزوهش علاوه بر صفات كمى (جدول r)، صفات كيفى از

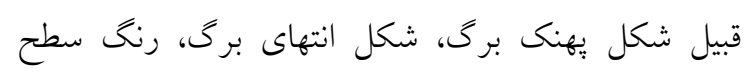

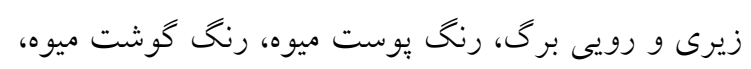
تيبٍ دمبرى و وجود كرى در سطح ميوه ارزيابى شدند. به منظور بررسى ساختار زنوتيبى نمونههاى سنجا، ابتدا استخراج DNA از برگهاى سر شاخههاى جوان كياه توسط روش CTAB تغيير يافته (Vroh et al., 1996)

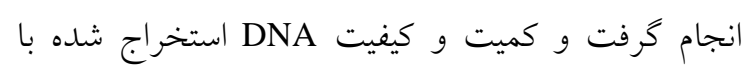

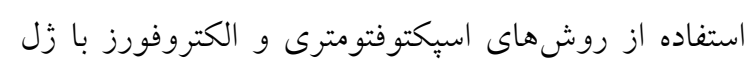

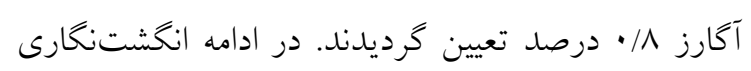

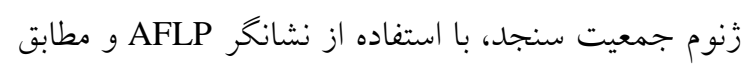
با روش وس و همكاران (Vos et al., 1995) انجام شد.

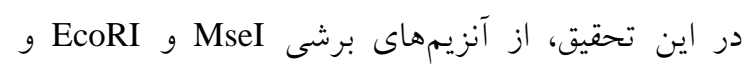

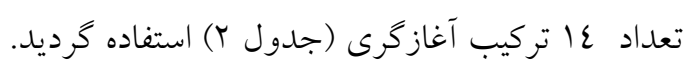
تجزيه آمارى دادهها: در مورد دادههاى كمى و كيفى تعى جابل

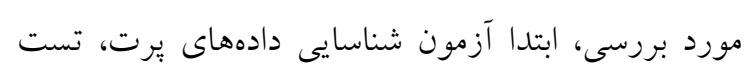

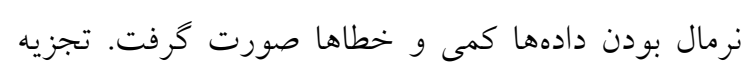

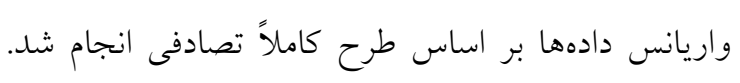
ضرايب همبستخى فنوتييى بين ميانخين صفات محاسبه

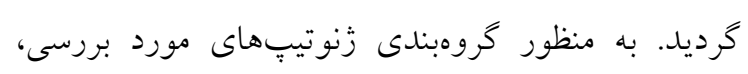

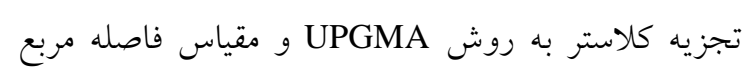
اقليدو سى با استفاده از متغيرهاى استاندارد شده انجام شد. تجزيههاى آمارى از طريق نرمافزارهاى 20 SPSS و MINITAB 16.2.0
زنتيكى زنوتيبهاى مختلف سنجد (07 زنوتيسֶ) مربـوط

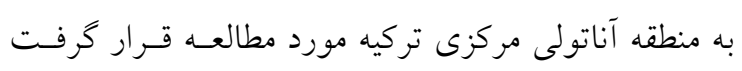

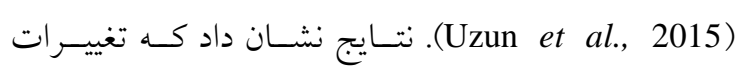

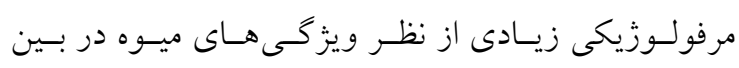

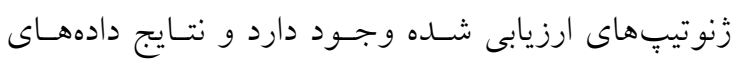

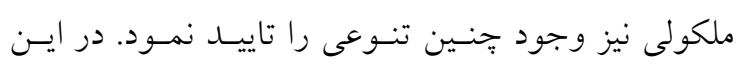

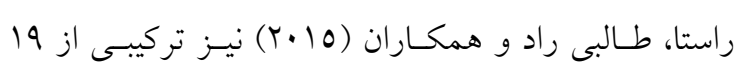

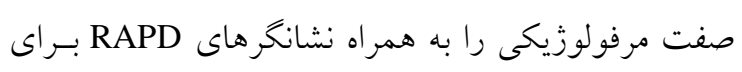
مطالعه تنوع زنتيكى و وجود يا عـدم وجـود ارتبـاط بسين تنوع زنتيكى وخصوصيات مرفولوزيكى را بررسى كردنسـ.

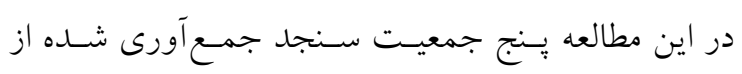

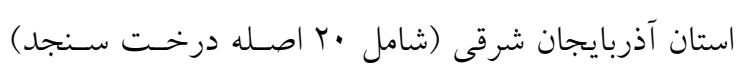

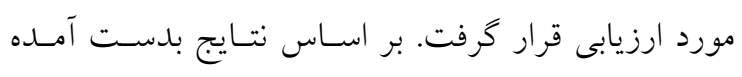

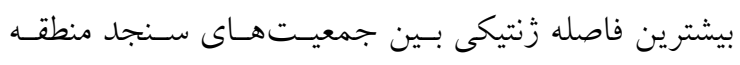

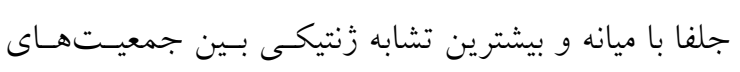

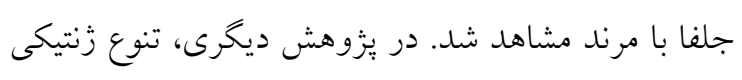
زرميّاسم سنجد در استان آذربايجان غربى توسط اسـديار

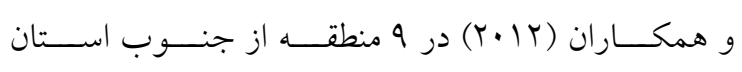

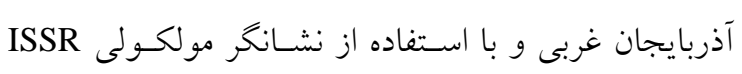

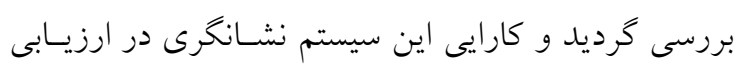
تنوع زنتيكى سنجد به اثبات رسيد. منطقه شمال غرب كشور يكى از خاستخاههـاى مهـم كيـاه

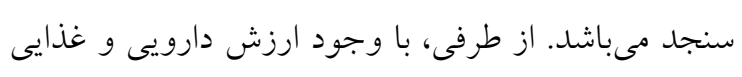

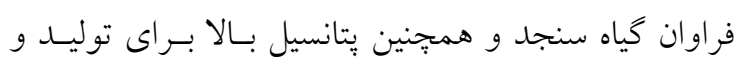
صادرات اين محصول به بازارهاى جهانى، متأسفانه مطالعه جندانى روى خصوصيات رويشى و زنتيكى سنجد بـويزه

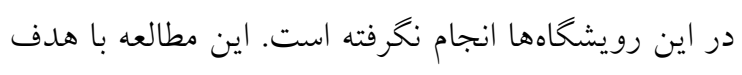

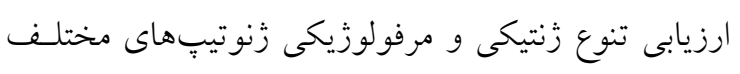

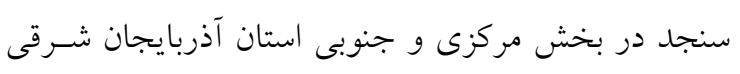

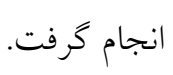

مواد و روشام حروشا مواد گياهى: مواد گياهى مورد استفاده در يزوهش حاضر، 
جدول ا - كد، نام و مكان زُنوتيبهاى سنجد مورد مطالعه

Table 1. The code, name and location of evaluated Russian olive genotypes

\begin{tabular}{|c|c|c|c|}
\hline $\begin{array}{c}\text { كد زنوتيڤ } \\
\text { Genotype code }\end{array}$ & $\begin{array}{c}\text { مكان زتوتيبِ } \\
\text { Genotype location }\end{array}$ & $\begin{array}{c}\text { كد زنوتيبٍ } \\
\text { Genotype code }\end{array}$ & $\begin{array}{c}\text { مكان زَتوتيِ } \\
\text { Genotype location }\end{array}$ \\
\hline G01 & $\begin{array}{c}\text { تبريز } \\
\text { Tabriz }\end{array}$ & G16 & $\begin{array}{c}\text { ملكان } \\
\text { Malekan }\end{array}$ \\
\hline G02 & $\begin{array}{l}\text { Tabriz } \\
\text { Tبريز }\end{array}$ & G17 & $\begin{array}{c}\text { ملكان } \\
\text { Malekan }\end{array}$ \\
\hline G03 & $\begin{array}{l}\text { Tabriz } \\
\text { Tبزيز }\end{array}$ & G18 & $\begin{array}{c}\text { ملكان } \\
\text { Malekan }\end{array}$ \\
\hline G04 & $\begin{array}{l}\text { Tabriz } \\
\text { Tبريز }\end{array}$ & G19 & $\begin{array}{c}\text { ملكان } \\
\text { Malekan }\end{array}$ \\
\hline G05 & تبريز & G20 & $\begin{array}{c}\text { مراغه } \\
\text { Maragheh }\end{array}$ \\
\hline G06 & $\begin{array}{l}\text { Tabriz } \\
\text { Tبزيز }\end{array}$ & G21 & $\begin{array}{c}\text { مراغه } \\
\text { Maragheh }\end{array}$ \\
\hline G07 & Tabriz & G22 & $\begin{array}{c}\text { مراغه } \\
\text { Maragheh }\end{array}$ \\
\hline G08 & ت & G23 & $\begin{array}{c}\text { مراغه } \\
\text { Maragheh }\end{array}$ \\
\hline G09 & $\begin{array}{l}\text { Tabriz } \\
\text { Tبريز }\end{array}$ & G24 & $\begin{array}{c}\text { مراغه } \\
\text { Maragheh }\end{array}$ \\
\hline G10 & Tabriz & G25 & $\begin{array}{c}\text { مراغه } \\
\text { Maragheh }\end{array}$ \\
\hline G11 & $\begin{array}{l}\text { Tabriz } \\
\text { Tبريز }\end{array}$ & G26 & $\begin{array}{c}\text { مراغه } \\
\text { Maragheh }\end{array}$ \\
\hline G12 & $\begin{array}{c}\text { تبريز } \\
\text { Tabriz }\end{array}$ & G27 & $\begin{array}{c}\text { مراغه } \\
\text { Maragheh }\end{array}$ \\
\hline G13 & $\begin{array}{c}\text { ملكان } \\
\text { Malekan }\end{array}$ & G28 & $\begin{array}{c}\text { مراغه } \\
\text { Maragheh }\end{array}$ \\
\hline G14 & $\begin{array}{c}\text { ملكان } \\
\text { Malekan }\end{array}$ & G29 & $\begin{array}{c}\text { مراغه } \\
\text { Maragheh }\end{array}$ \\
\hline G15 & $\begin{array}{c}\text { ملكان } \\
\text { Malekan }\end{array}$ & G30 & $\begin{array}{c}\text { مراغه } \\
\text { Maragheh }\end{array}$ \\
\hline
\end{tabular}

نشـانخر i ام هنخـام وجـود نـوار و (1-fi) فراوانى قطعـه

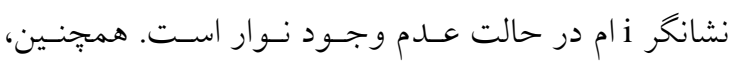
پارامترهاى تعداد آلل مؤثر، ميزان شاخص نسى و شـاخص

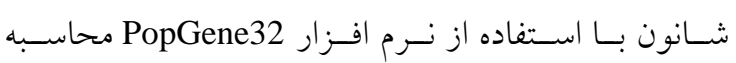
كرديدند. نتايج و بحث ارزيابى مرفولوزيكى زرميلاسـم ســنجد: نتـايج تجزيـهـ واريانس صفات كمى و كيفى بيانحر وجود تفاوت معنسى -
براى دادههاى نشانخر ملكولى ابتدا ماتريس صفر و يـك،

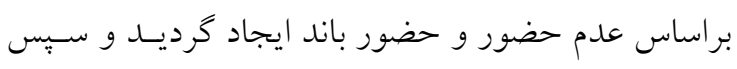
تشابه بين زنوتيبها با استفاده از ضرايب تشابه جاكـارد و دايس محاسبه گرديدند. گروهبندى زنوتيبٍها با استفاده از ماتريس تشابه محاسبه شد و الخــوريتم UPGMA در نــرم افزار NTSYS انجام گرفت. شـاخص محتـوى اطلاعـات جند شكلى ' مطابق با رابطه PICi = 2 fi (1-fi) بر آورد شد

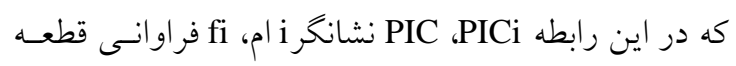

1- Polymorphism Information Content 


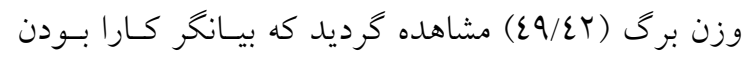

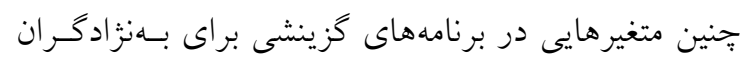
كياهى است.

وجود تنوع در زرميلاسم سنجد از طريق مطالعه صـفات

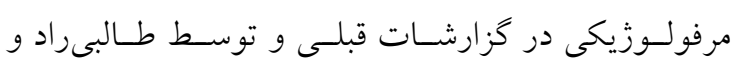

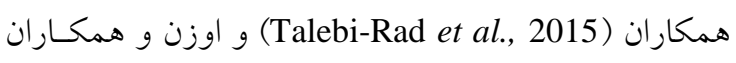
نيز كزارش شده است. طـالبى راد و (Uzun et al., 2015)

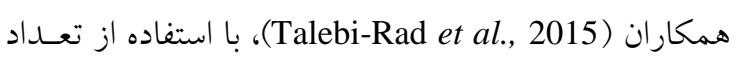
19 صـفت مرفولـوزيكى تنـوع زنتيكسى را در ميـان يـنج

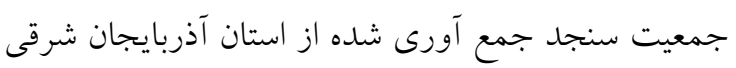

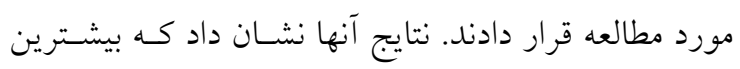

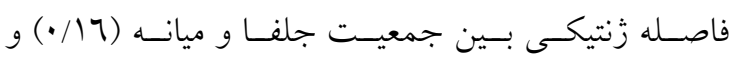

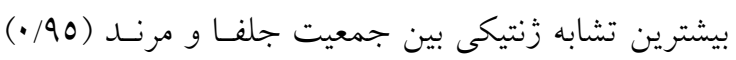
مشاهده شل.
دار بين زنوتيستهـاى مختلـف سـنجد از لحـاظ صـفات

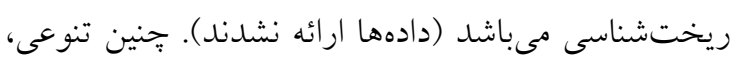

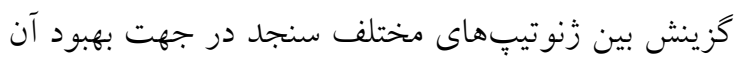
از طريق برنامههاى بهنزادى گياهى را امكان يذير مى سئسازد.

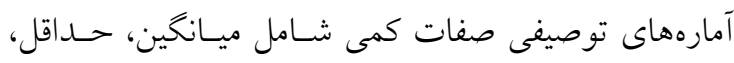

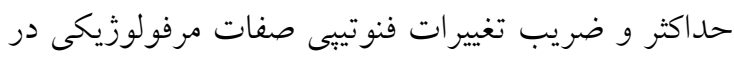

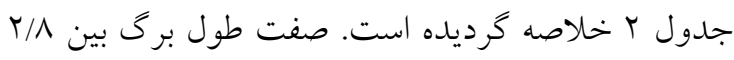

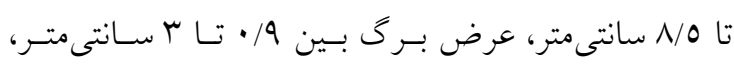

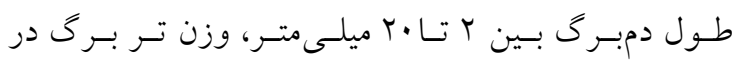

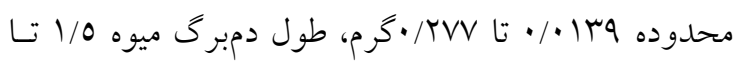

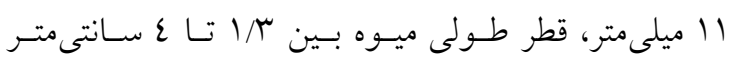

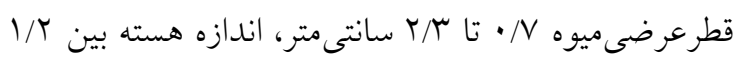

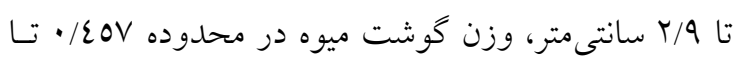

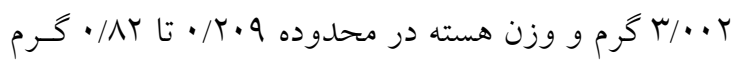

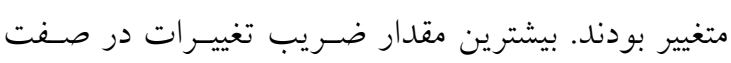

\section{جدول r- آمارهاى توصيفى صفات مرفولوزيكى كمى در زنوتيبٍ إى سنجد}

Table 2. Descriptive statistics of morphological-quantitative traits among Russian olive genotypes

\begin{tabular}{|c|c|c|c|c|}
\hline $\begin{array}{l}\text { صفت } \\
\text { Trait }\end{array}$ & $\begin{array}{l}\text { ميانگين } \\
\text { Mean }\end{array}$ & $\begin{array}{c}\text { ضريب تغييرات } \\
\text { Coefficient of variation }\end{array}$ & حداقل & حلح \\
\hline $\begin{array}{l}\text { طول برك (cm) } \\
\text { Leaf length }\end{array}$ & 5.40 & 21.94 & 2.8 & 8.50 \\
\hline عرض برى (cm) ع (cm) & 1.56 & 23.78 & 0.9 & 3.00 \\
\hline $\begin{array}{c}\text { طول دمبرى (mm) } \\
\text { Petiole length }\end{array}$ & 9.93 & 32.75 & 2.00 & 20.00 \\
\hline $\begin{array}{l}\text { وزن برى (gr) } \\
\text { Leaf weight }\end{array}$ & 0.10 & 49.42 & 0.01 & 0.27 \\
\hline $\begin{array}{l}\text { طول دم ميوه (mm) } \\
\text { Fruit tail length }\end{array}$ & 4.72 & 48.01 & 1.50 & 11.00 \\
\hline 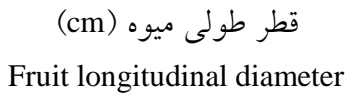 & 2.51 & 19.91 & 1.30 & 4.00 \\
\hline $\begin{array}{l}\text { قطر عرضى ميوه (cm) } \\
\text { Fruit crosswise diameter }\end{array}$ & 1.55 & 18.80 & 0.70 & 2.30 \\
\hline $\begin{array}{l}\text { اندازه هسته (cm) size } \\
\text { Fruit stone size }\end{array}$ & 2.02 & 18.26 & 1.20 & 2.90 \\
\hline وزن كوشت ميوه (gr) & 1.28 & 37.96 & 0.45 & 3.00 \\
\hline $\begin{array}{l}\text { وززن هسته (gr) } \\
\text { Fruit stone weight }\end{array}$ & 0.53 & 22.98 & 0.20 & 0.82 \\
\hline
\end{tabular}




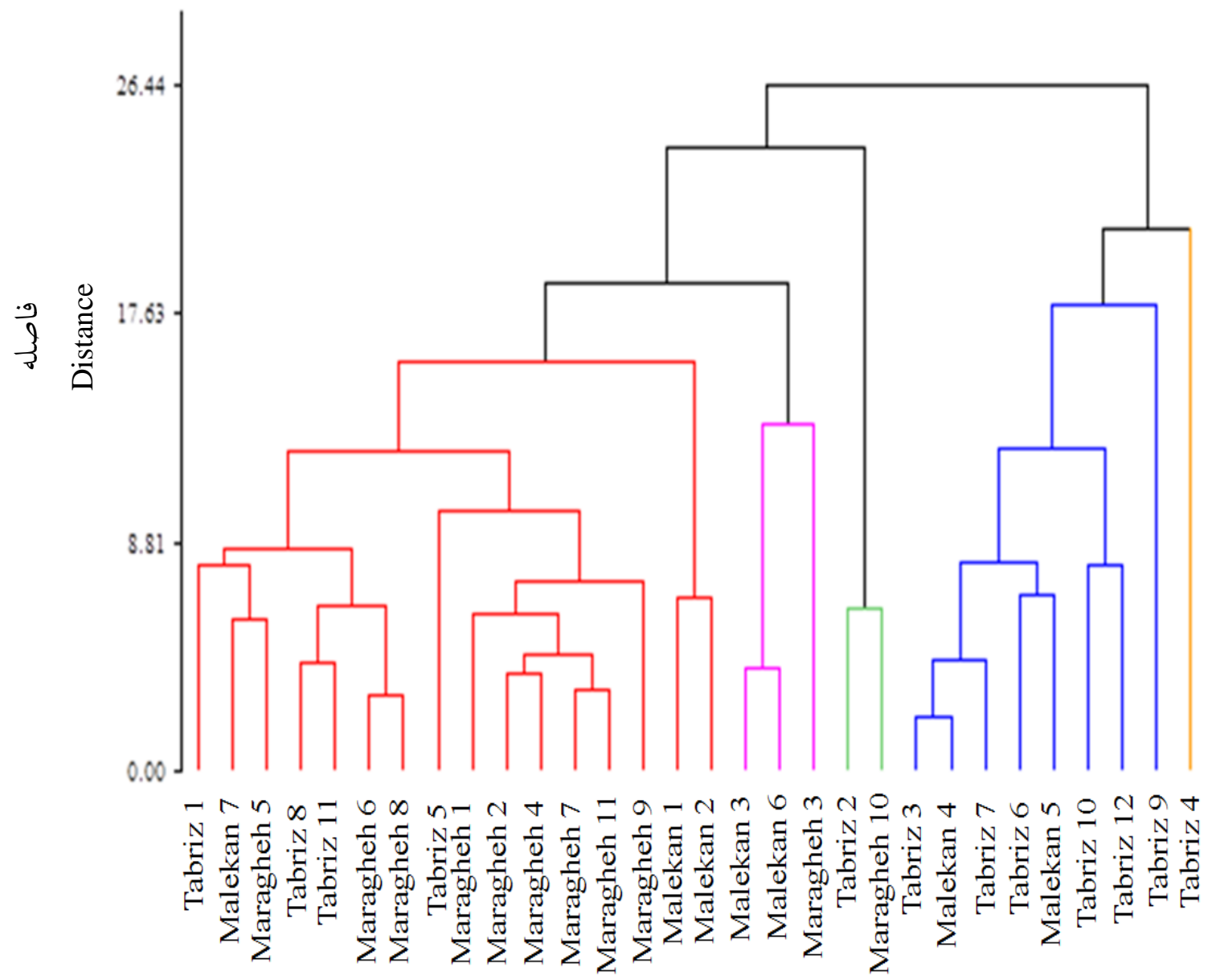

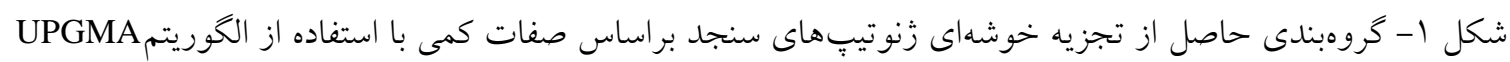

Figure 1. Dendrogram (UPGMA algorithm) of 30 Russian olive genotypes based on genetic distances calculated using quantitative traits

كروهبندى ذكر شده، بيشترين ميزان فاصله بين دو كروه ع و ه (سا/T) و نزديكترين گروهها، گروه او ب با فاصله

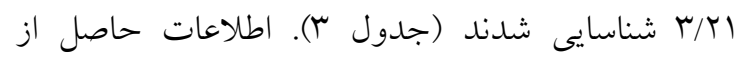

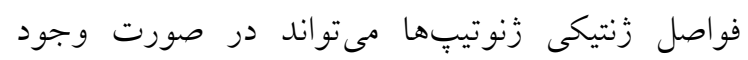

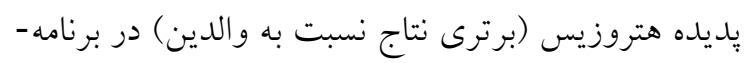

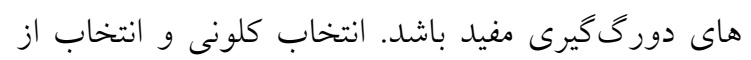

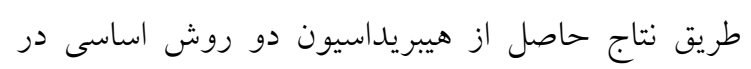

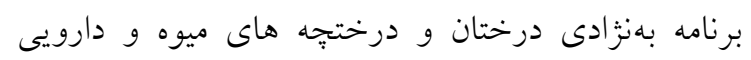

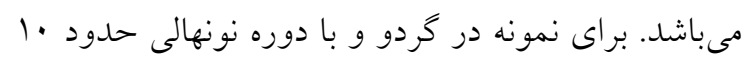

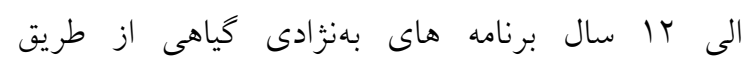

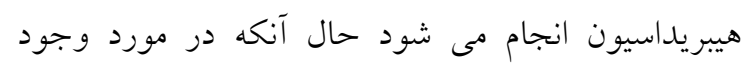

محققين معمولاً جهت انتخاب بهترين والدين در هر تلاقى در بيى ارقام يا زنوتيبهايى هستند كه از هم دور

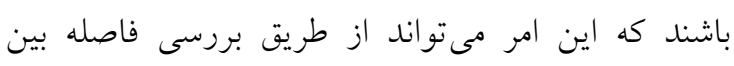

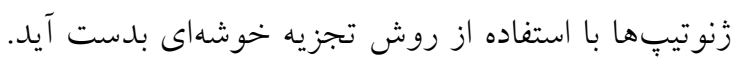

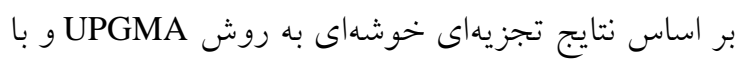

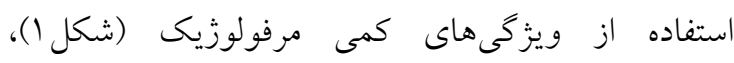

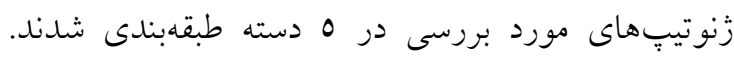

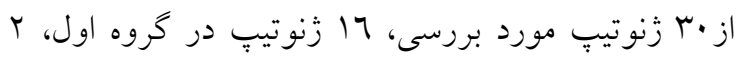

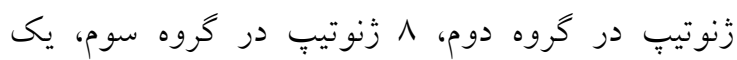

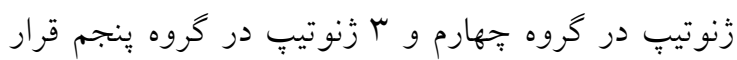

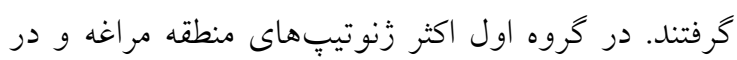

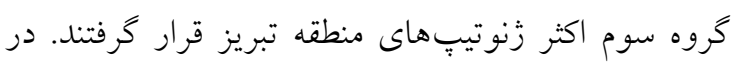


در اين مطالعه توانمندى نشانكر مورد استفاده در مطالعه تنوع زنتيكى زنوتيِهاى سنجد بوضوح نشان داده شد،

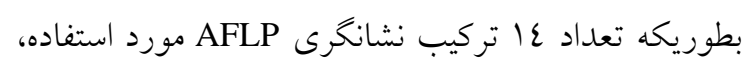

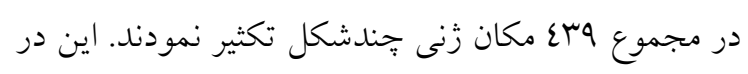
حالى است كه مطالعه مشابه با استفاده از 11 تركيب

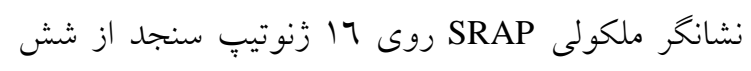

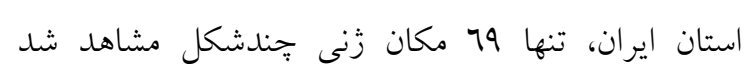
(Taghipour, 2013)

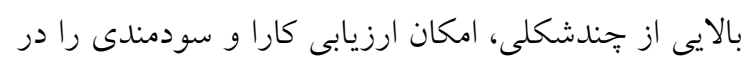
بررسى هاى مربوط به تنوع زنتيكى كياه سنجد فراهم

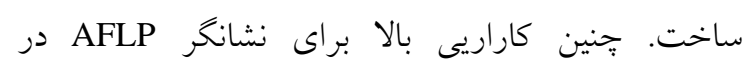

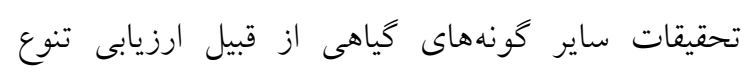
زنتيكى 97 زنوتيب كياه . Tectona grandis L. با استفاده

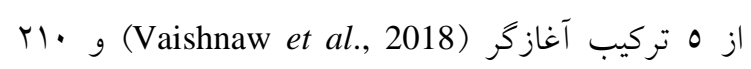
زنوتيب كياه . Dactylis glomerata L. بين عاب از جمعيت

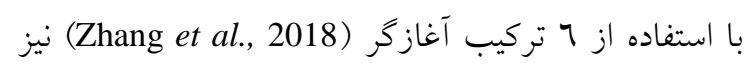

$$
\text { كز ارش شده است. }
$$

هزروزيس (برترى نتاج نسبت به والدين) در سنجد در اين تحقيق، مشابه با كروهبندى صفات كمى، زنوتيبهاى سنجد با استفاده از ويزگى هاى كيفى و الكوريتم نيز در ه خروه مجزا قرار گرفتند (شكل Y Y). گروه اول شامل عا زنوتيب، گروه دوم ع زنوتيب، گروه

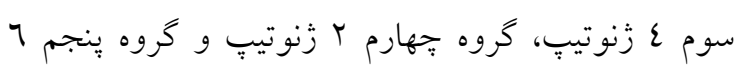

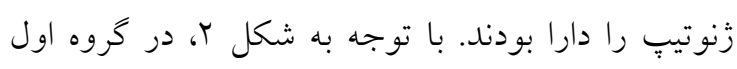

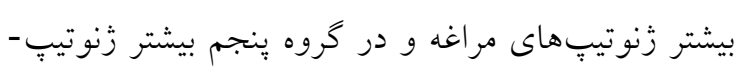

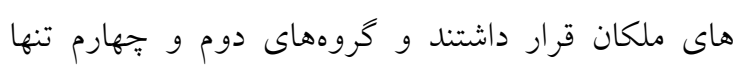
شامل زنوتيبٍهاى تبريز بودند.

$$
\begin{aligned}
& \text { انغشتنغارى زرميلاسم سنجد با نشـانخرهاى AFLP: } \\
& \text { تعداد عا تركيـب نشـانگرى AFLP مـورد اسـتفاده قـرار }
\end{aligned}
$$

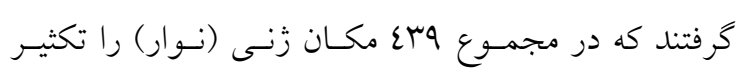

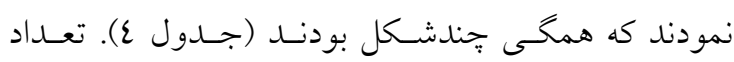

$$
\begin{aligned}
& \text { نوارهاى تكثيرى توسط تركيبات آغازگرى بين اله نوار در نور }
\end{aligned}
$$

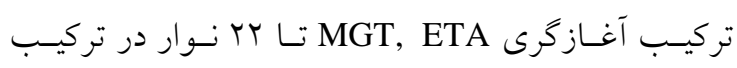

$$
\begin{aligned}
& \text { آغازكرى ECT, MGAG متغيير بودند (شكل r). }
\end{aligned}
$$

$$
\text { جدول r- فاصله بين جفت گروههاى حاصل از خوشهبندى زنوتيبٍهاى سنجد بر اساس صفات كمى }
$$

\begin{tabular}{|c|c|c|c|c|c|c|}
\hline $\begin{array}{c}\text { كروهoup } 5 \\
\text { Group }\end{array}$ & 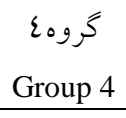 & $\begin{array}{c}\text { ros } \\
\text { Group } 3\end{array}$ & $\begin{array}{c}\text { ros } \\
\text { Group } 2\end{array}$ & $\begin{array}{c}1 \text { كروها } 1 \\
\text { Group } 1\end{array}$ & - & $\begin{array}{c}\text { تعداد زنوتيب } \\
\text { Number of Genotype }\end{array}$ \\
\hline & & & & 0 & $\begin{array}{c}1 \\
\text { Group } 1\end{array}$ & 16 \\
\hline & & & 0 & 4.18 & $\begin{array}{l}r \text { كروه } \\
\text { Group } 2\end{array}$ & 2 \\
\hline & & 0 & 6.43 & 3.21 & $\begin{array}{l}r \text { كروه } 3 \\
\text { Group } 3\end{array}$ & 8 \\
\hline & 0 & 3.97 & 5.64 & 4.02 & $\begin{array}{l}\varepsilon \text { عروه } \\
\text { Group } 4\end{array}$ & 1 \\
\hline 0 & 6.63 & 5.84 & 4.15 & 3.18 & $\begin{array}{l}0.0 \\
\text { Group } 5\end{array}$ & 3 \\
\hline
\end{tabular}

Table 3. The distance between different group pairs, resulted from clustering of Russian olive genotypes based on quantitative traits 


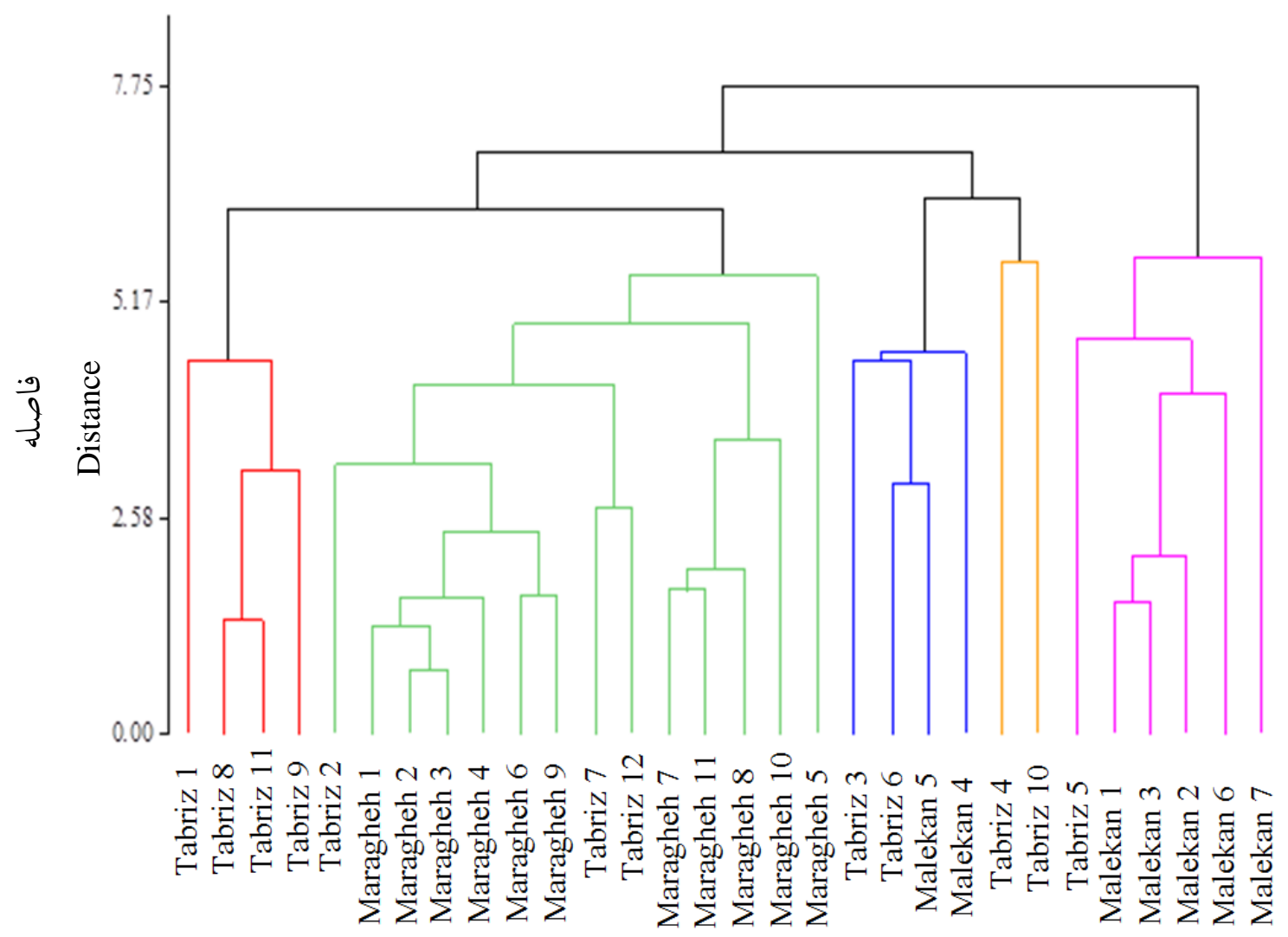

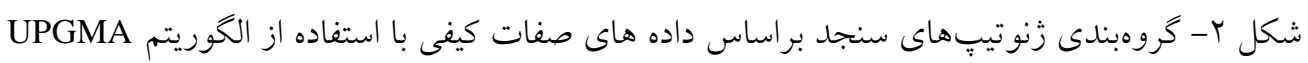

Figure 2. Dendrogram (UPGMA algorithm) of 30 Russian olive genotypes based on genetic distances calculated using qualitative traits

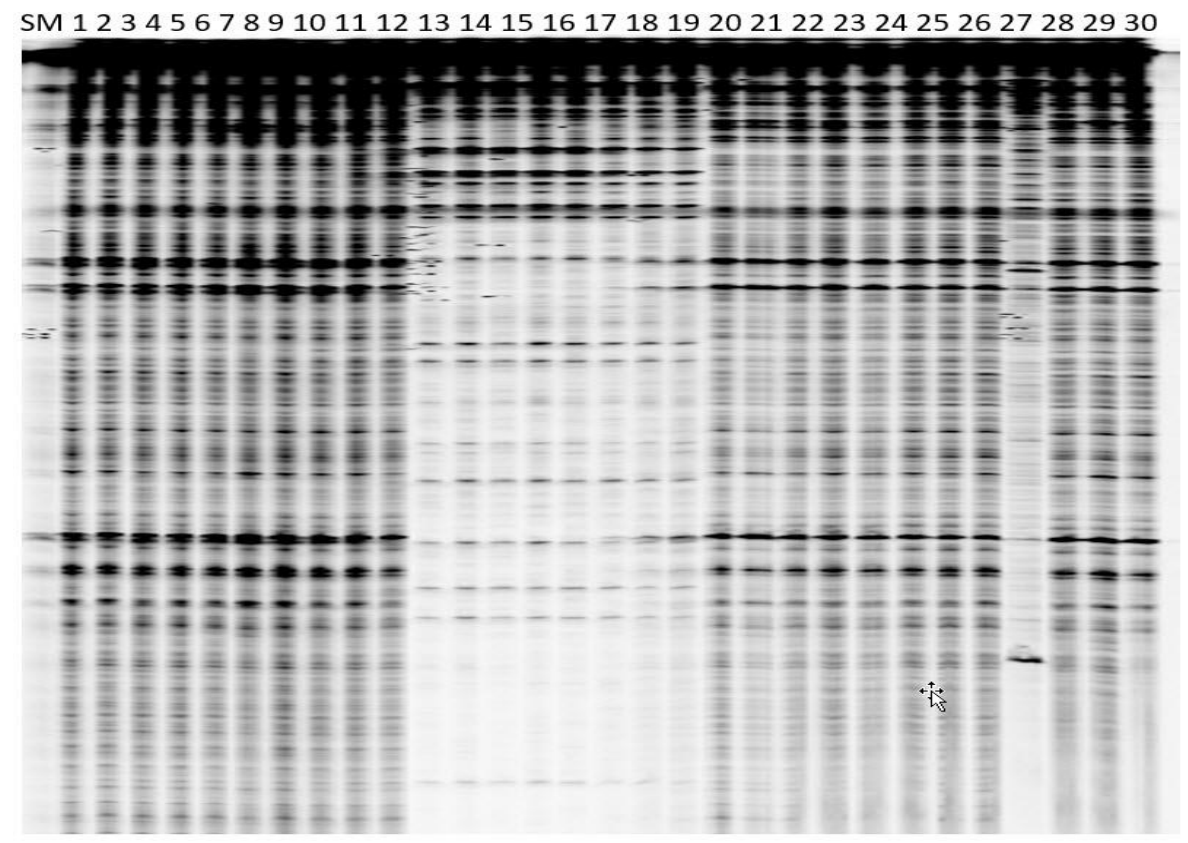

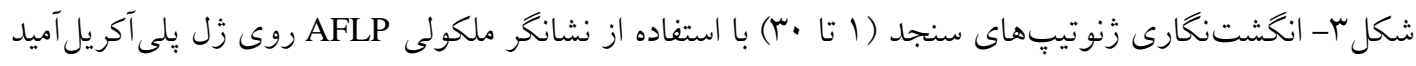

Figure 3. Fingerprinting of Russian olive genotypes (1-30) using AFLP markers on Polyacrylamide gel 


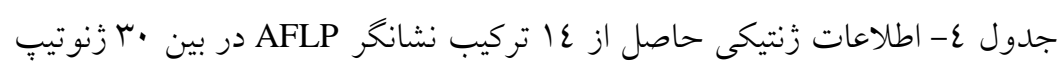

Table 4. The genetic information generated by 14 AFLP primer combinations among 30 genotypes of Russian olive

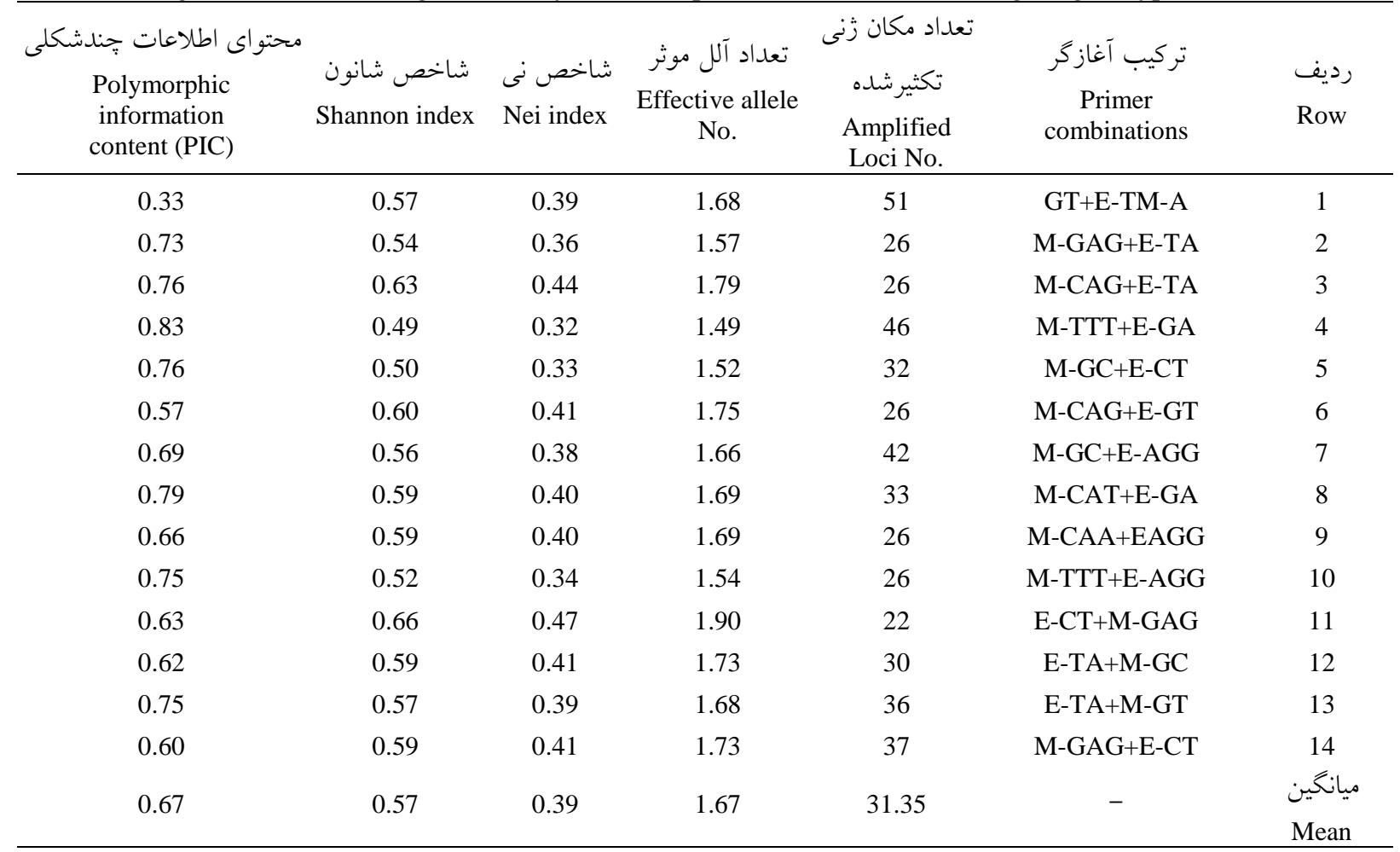

كمترين ميزان اطلاعات جندشـكلى (PIC) بـراى تركيـبـ

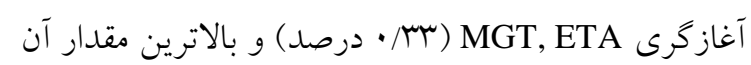
بـراى تركيـب آغـازكرى MTTT, EGA (س// • درصــد)

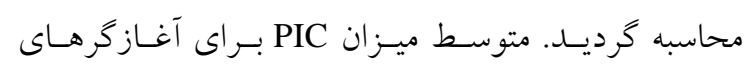

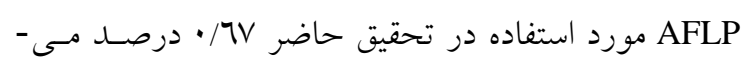
باشــد (جــدول ع). شـاخص PIC محتــواى اطلاعــاتى

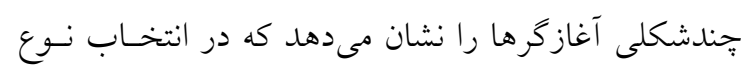
نشانگر، براى بدست آوردن جندشكلى كافى، نـوع رابطـه

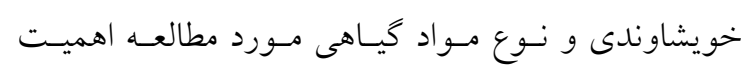

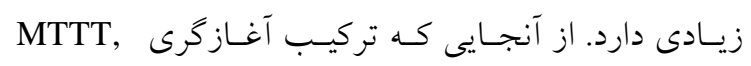
PIC EGA

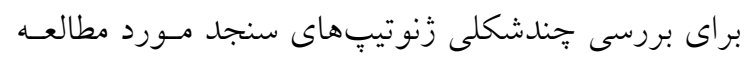

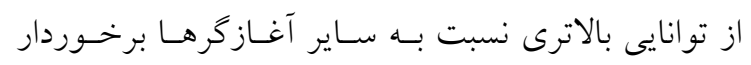

كروهبندى زنوتيِهاى سنجد با استفاده از نشانخر AFLP در اين مطالعه شباهت زنتيكى زنوتيڤهاى مورد مطالعه با

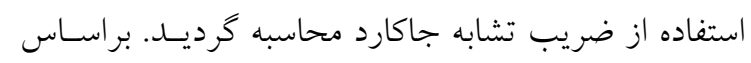

در تحقيق حاضر، بيشـترين تعـداد آلـل مـوثر مربـوط بـهـ

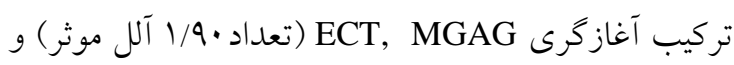
كمترين تعـداد آلـل مــوثر مربـوط بـهـ تركيـبـ آغـازگرى MTTT, EGA

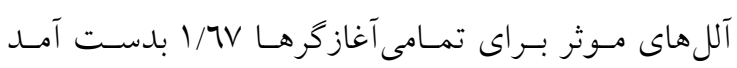
(جدول ع). با توجه به شاخص هاى مختلـف تنسوع، تنسوع زنتيكى بالايى در بين زنوتيبهاى مختلف سـنجد وجـود

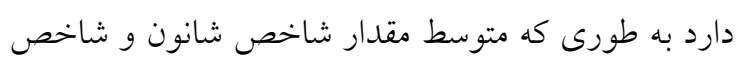
تنوع زنى نى به ترتيب برابر با OV/ • و وس/ • بدست آمـد.

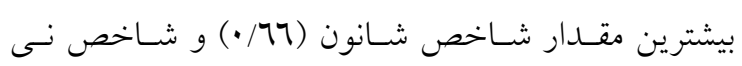

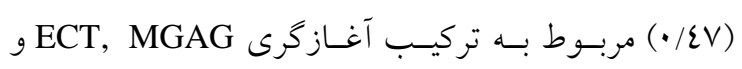
كمترين مقدار اين شاخص ها به ترتيب بـا مقـادير وعـ/ • و ץ"/ •در تركيب آغاز گرى MTTT, EGA مشاهده گرديد. ECT, به عنوان يك نتيجه كيرى كلى، تركيـب آغـازگرى

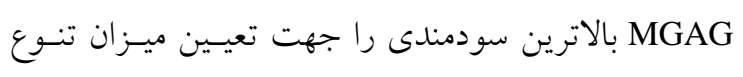
زنتيكى بين زنوتيبٍ هاى سنجد مورد مطالعه دارا مىباشد. 
اين كياه از طريق قلمه باشد. به نظر مىرسد كه زنوتيـٍ -

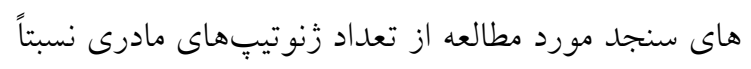

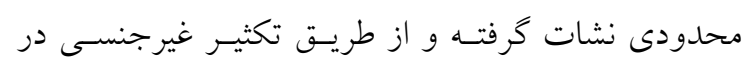

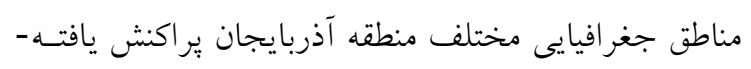

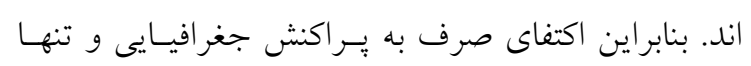

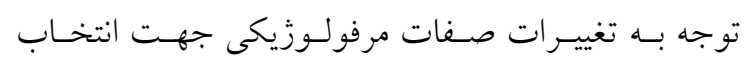

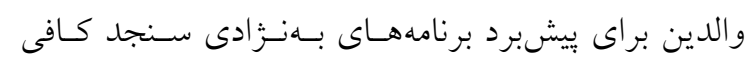

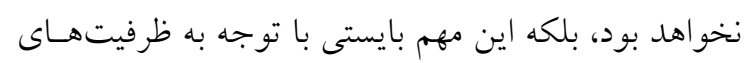

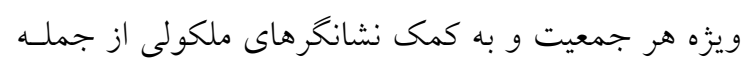

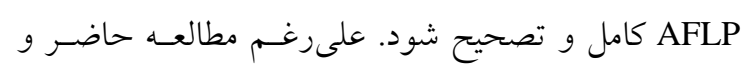

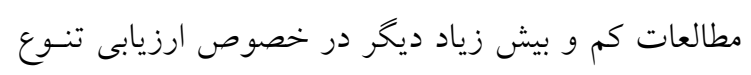

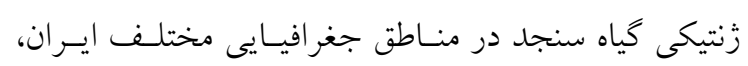

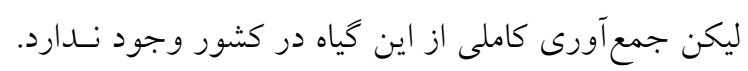

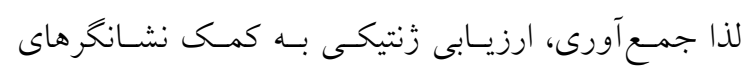

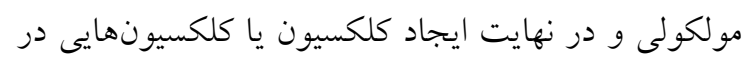

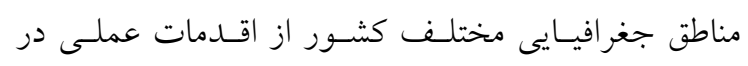

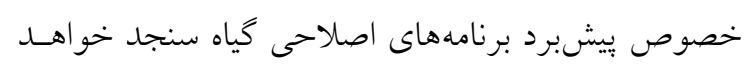

تجزيه به مختصات اصلى جهت كـاهش حجــم دادههـا و

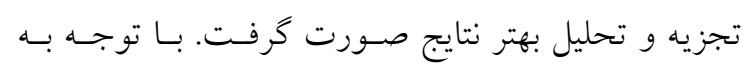

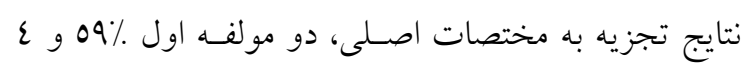

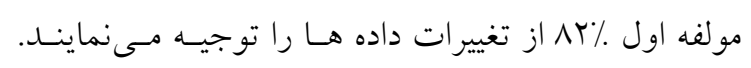

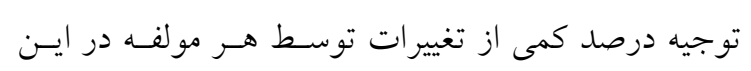

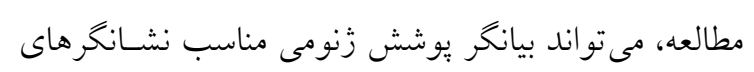

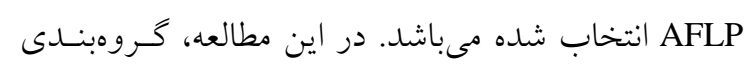

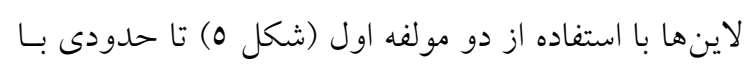

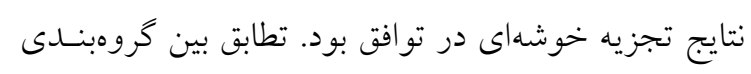

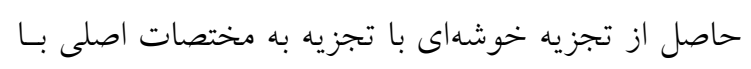

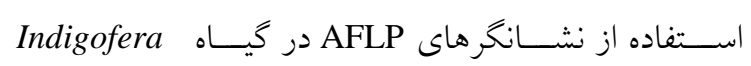

Fan et al., ) نيـز خــزارش شـــ pseudotinctoria

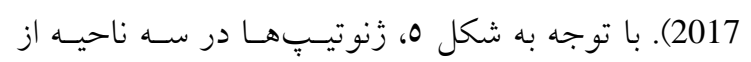

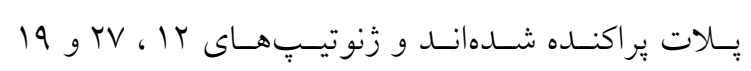

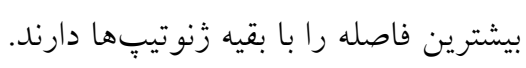

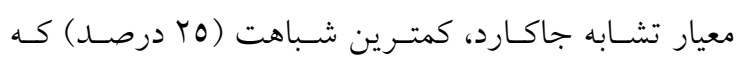
بيانگر بيشترين واكرايى است بين زنوتيبٍ هاى 19 (منطقسه

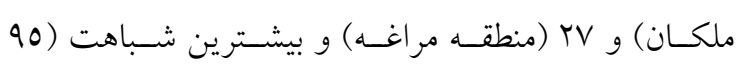

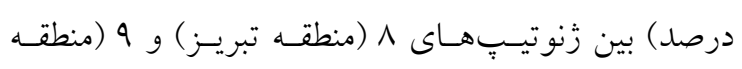

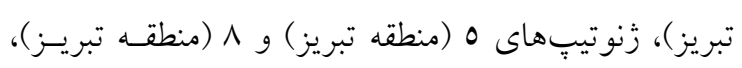

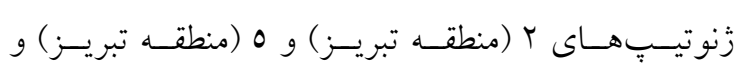

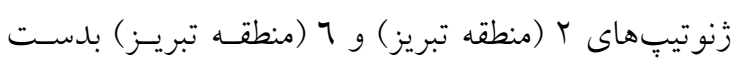

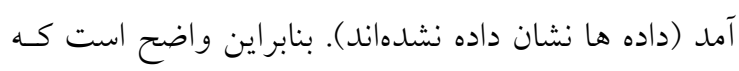

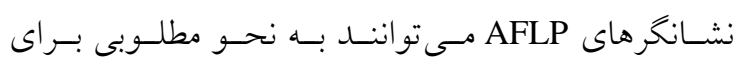

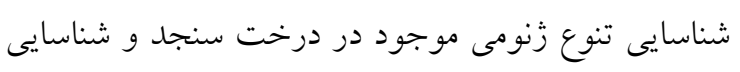

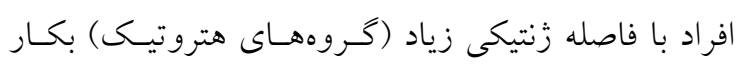

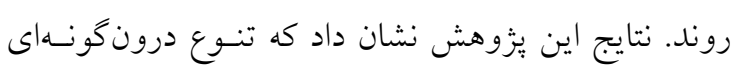

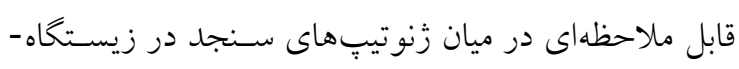

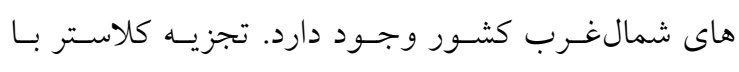
اسـتفاده از الخــوريتم UPGMA و معيـار تشـابه جاكـارد،

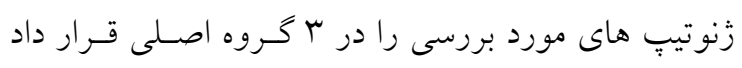

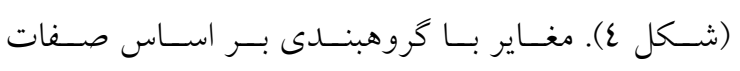

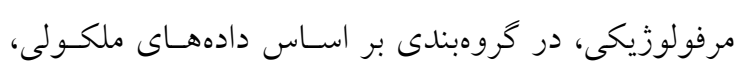

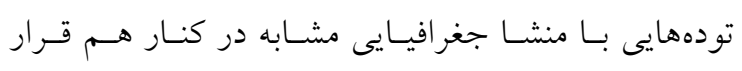

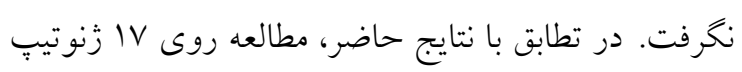

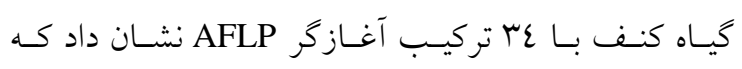

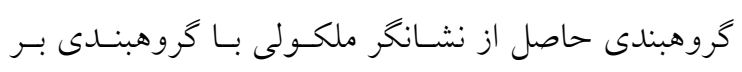
اساس صفات مرفولوزيكى همخوانى نداشت. در توضسيح

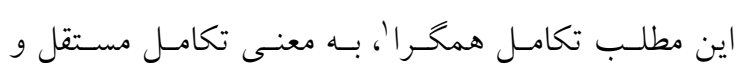

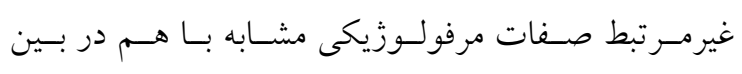

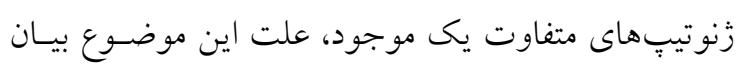

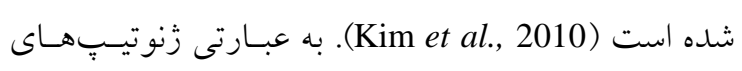
متفاوت سنجد كه ارتبـاط زنتيكسى زيـادى بـاهم ندارنــا، هنغامى كه در شـرايط اقليمى و محيطى مشـابه (منـاطق

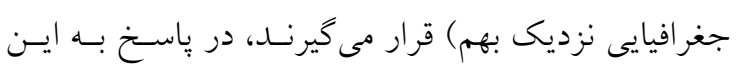

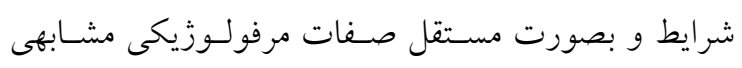
بيدا مى كنند. ليكن در مورد كياه سنجد يكى دليل احتمـالى

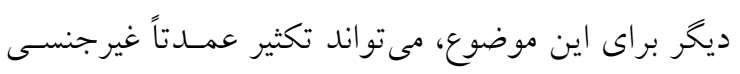

1- Convergent evolution 


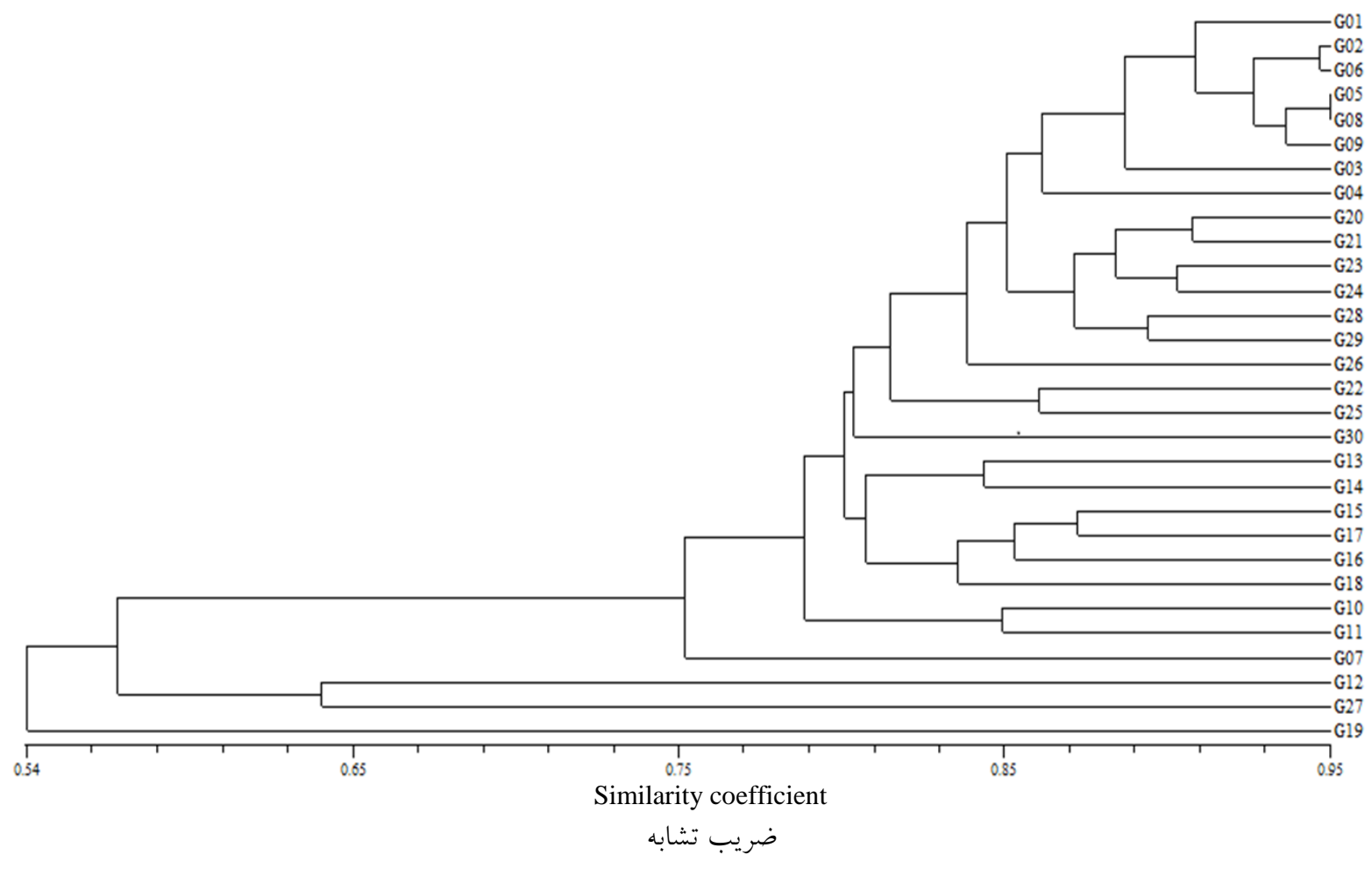

شكل ع- گروه بندى زنوتيڤهاى سنجد با استفاده از نشانگرهاى AFLP و الكوريتم UPGMA و معيار تشابه جاكارد.

Figure 4. Cluster analysis using UPGMA algorithm and Jaccard similarity coefficient of 30 Russian olive genotypes based on AFLP markers

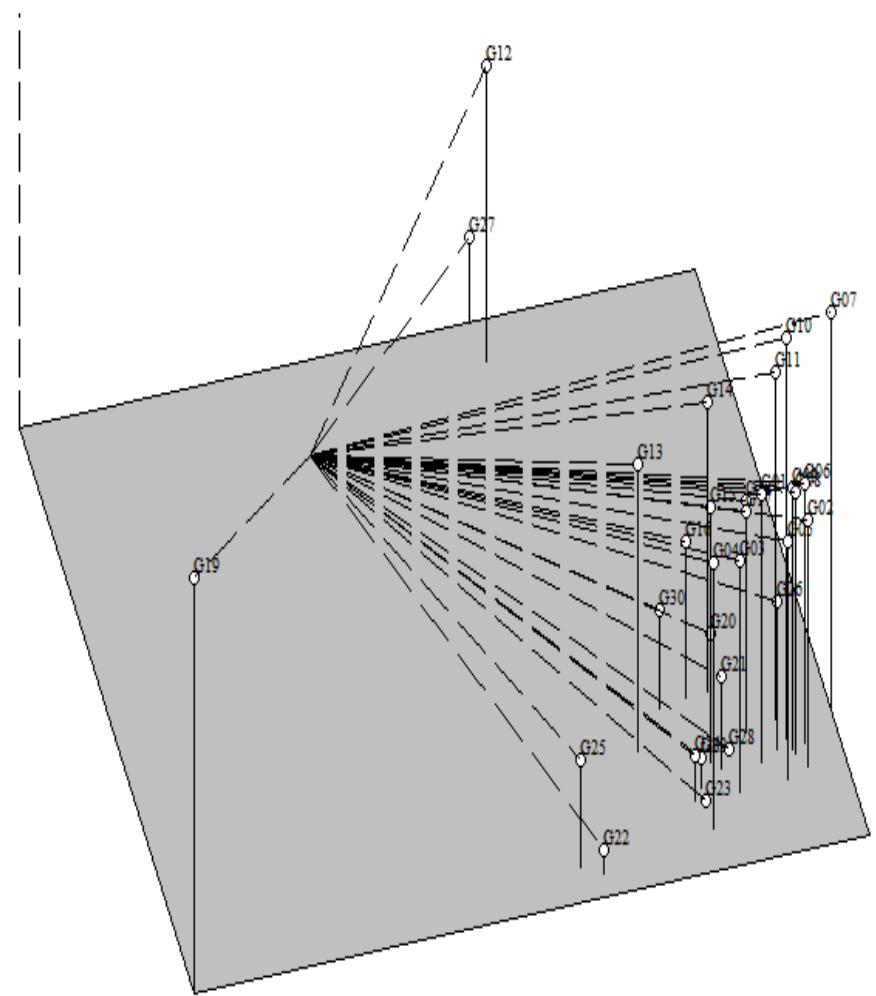

AFLP شكل 0- نمودار بِراكنش سه بعدى زنوتيبٍ هاى سنجد بر اساس تجزيه به محورهاى اصلى با استفاده از نشانگر

Figure 5. Trimensional scatter plot of Russian olive genotypes based on principle co-ordinate analysis using AFLP markers 


$$
\begin{aligned}
& \text { جغرافيايى زنوتيڤها همخوانى نشان داد. بـر ايسن اسـاس } \\
& \text { ضرورى است تصميم گيرى در خصوص انتخـاب والـدين } \\
& \text { تلاقى داراى حداكثر فاصله زُنتيكى ازهمـديخر صـرفا بـا } \\
& \text { توجه به صفات مرفولوزيكى صورت نخيرد. نتايج تجزيسه }
\end{aligned}
$$

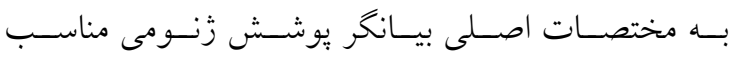

$$
\begin{aligned}
& \text { نشانكرهاى AFLP انتخاب شده در اين مطالعسه بـود و در } \\
& \text { اين بين تركيب آغـازگرى MTTT و EGA داراى كـارايى } \\
& \text { بالايى در تمايز زنوتيبهاى سنجد مورد مطالعه بود. }
\end{aligned}
$$

$$
\begin{aligned}
& \text { اين تحقيق در واقـع اولـين گـزارش علمسى در خصـوص } \\
& \text { استفاده از نشـانخر هاى AFLP در بررسى تنسوع زنتيكى } \\
& \text { ســجد مس باشـــ و نتـايج نشـان داد كـه ايسن نشـانكرها } \\
& \text { مى توانند به نحو مطلوبى بـراى شناسـايى تنسوع در سـطح }
\end{aligned}
$$

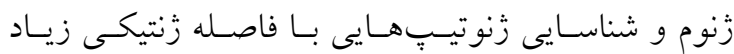

$$
\begin{aligned}
& \text { (كروههاى هتروتيك) بكار روند. بر اساس گروهبنـدى بـه }
\end{aligned}
$$

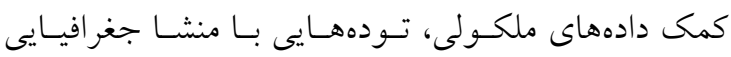

$$
\begin{aligned}
& \text { مشابه در كنار هم قرار نخرفتند، ليكن خروهبندى بر اساس } \\
& \text { صفات مرفولوزيكى كمى و كيفى تا حدود زيادى با توزيع }
\end{aligned}
$$

\section{References}

Arohonka, T. and Rousi, A. (1980). Karyotypes and C-bands in Shepherdia and Elaeagnus. Annales Botanici Fennici. 17: 258-263.

Asadiar, L.S., Rahmani, F. and Siami, A. (2012). Assessment of genetic diversity in the Russian olive (Elaeagnus angustifolia) based on ISSR genetic markers. Revista Ciencia Agronomica, 44: 310-316.

Doveri, S., Sabino Gil, F., Diaz, A., Reale, S., Busconi, M., Camara Machado, A., Martin, A., Fogher, C., Donini, P. and Lee, D. (2008). Standardization of a set of microsatellite markers for use in cultivar identification studies in olive (Olea europaea L.). Science Horticulture (Amsterdam), 116: 367-373.

Elmi, F., Dehghan, G. and Beigzadeh, B. (2016). Qualitative and quantitative changes of essential composition in the flowers of some populations of Elaeagnus angustifolia. Advanced Herbal Medicine, 2(1): 1-6.

Fan, Y., Zhang, C., Wu, W., He, W., Zhang, L. and Ma, X. (2017). Analysis of Genetic Diversity and Structure Pattern of Indigofera pseudotinctoria in Karst Habitats of the Wushan Mountains Using AFLP Markers. Molecules, 22: 1734.

Fufa, H.P., Baenizger, S., Beecher, B.S., Dweikat, I., Graybosch, R.A. and Eskridge, K.M. (2005). Comparison of phenotypic and molecular marker-based classifications of hard red winter wheat cultivars. Euphytica, 145: 133-146.

Guo, Y.P., Saukel, J., Mittermayr, R., Ehrendorfer, F. (2005). AFLP analysis demonstrates genetic divergence hybridization, and multiple polyploidizations in the evolution of Achilla (AsteraceaeAnthemideae). New Phytologist, 166: 273-290.

Kim, W.J., Kim, D.S., Kim, S.H., Kim, J.B., Goh, E.J. and Kang, S.I. (2010). Analysis of genetic similarity detected by AFLP and PCoA among genotypes of kenaf (Hibiscus cannabinus L.). Journal of Crop Science and Biotechnology, 13: 243-249.

Pan, C., Zhao, H., Zhao, X. Liu, J., Liu, L., Hou, Y. and Zhang, L. (2011). Pollination ecology and breeding system of Elaeagnus angustifolia. IEEE Conferences. The $2^{\text {nd }}$ international conference on multimedia technology, July 26-28, Hangzhou, $\mathrm{CH}$. 
Sun, M., Lin, Q. (2010). A revision of Elaeagnus L. (Elaeagnaceae) in mainland China. Journal of Systematics and Evolution, 48: 356-390.

Taghipour, N. (2013). The study of genetic diversity among Elaegnus angostifolia L. genotypes using morphological and molecular markers (SRAP). MSc. thesis. University of Orumiyeh, Orumiyeh, Iran (In Persian).

Talebi-Rad, H., Onsori, H. and Akrami, S. (2015). Genetic diversity among Elaeagnus angustifolia L. population based on some morphological traits and random amplified polymorphic DNA markers. Iranian Journal of Genetics and Plant Breeding, 4: 17-24.

Vaishnaw, V., Mohammad, N., Wali, S.A., Kumar, R., Tripathi, S.B., Negi, M.S. and Ansari, S.A. (2018). AFLP markers for analysis of genetic diversity and structure of teak (Tectona grandis L.) in India. Canadian Journal of Forest Research, 45(3): 297-30.

Vos, P., Hogers, R., Bleeker, M., Reijans, M., Lee, T.v.d., Hornes, M., Friters, A., Pot, J., Paleman, J. and Kuiper, M. (1995). AFLP: a new technique for DNA fingerprinting. Nucleic Acids Research, 23: 4407-4414.

Vroh, B.I., Hravetg, L., Chandelier, A., Mergiai, G. and Dujardin, P. (1996). Improved RAPD amplification of recalcitrant plant DNA by use of activated charcoal during DNA extraction. Plant Breeding, 115: 205-206.

Uzun, A., Celik, B., Karadeniz, T., Yilmaz, K.U. and Altintas, G. (2015). Assessment of fruit haracteristics and genetic variation among naturally growing wild fruit Elaeagnus angustifolia accessions. Turkish Journal of Agriculture and Forestry, 39: 286-294.

Zhang, C., Sun, M., Zhang, X., Chen, S., Nie, G., Peng, Y. Huang, L. and Ma, X. (2018). AFLPbased genetic diversity of wild orchardgrass germplasm collections from Central Asia and Western China, and the relation to environmental factors. PLOS ONE, |https://doi.org/10.1371/ journal. pone. 0195273 . 


\title{
Morphological and AFLP-Based Genetic Diversity Assessment of Elaeagnus angustifolia $\mathbf{L}$.
}

\section{Roya Zirak ${ }^{1}$, Ali Soleimani ${ }^{2, *, \#, ~ M e h r s h a d ~ Z e i n o l a b e d i n i ~}{ }^{3, \#, ~ H a m i d ~ H a t a m i ~ M a l e k i ~}{ }^{4}$ and Azizolah Kheiri ${ }^{5}$}

1- Former M.Sc., Department of Horticulture, Faculty of Agriculture, University of Zanjan, Zanjan, Iran

1- Associate Professor, Department of Horticulture, Faculty of Agriculture, University of Zanjan, Zanjan, Iran

3- Associate Professor, Agricultural Biotechnology Research Institute of Iran (ABRII), Agricultural Research, Education and Extension Organization (AREEO), Karaj, Iran

4- Associate Professor, Department of Plant Genetic and Production, Faculty of Agriculture, University of Maragheh, Maragheh, Iran

5- Assistance Professor, Department of Horticulture, Faculty of Agriculture, University of Zanjan, Zanjan, Iran

(Received: September 2, 2018 - Accepted: December 30, 2018)

\begin{abstract}
Genetic diversity among Russian olive genotypes in three different regions of East-Azerbaijan province (includes Tabriz, Maragheh and Malekan) were assessed using morphological and molecular (AFLP) markers. Results of the quantitative and qualitative traits statistics showed a significant genetic variation among studied germplasm and categorized them in five distinguished groups. The most number of genotypes from Maragheh region were in group 1, while, the group 3 consisted of the majority of genotypes from Tabriz region. All genotypes were analyzed with 14 EcoRI-MseI primer combinations. A total of 439 informative and polymorph AFLP markers was generated and analyzed. Based on Jaccard Similarity Index, the minimum genetic similarity was observed between genotype 19 (from Malekan region) and 27 (from Maragheh). The principal coordinate analysis (PCoA) showed the suitable genomic distribution of AFLP markers among individuals. The highest $(0.83 \%)$ and lowest $(0.33 \%)$ polymorphic information content achieved by primers combination MTTT-EGA and MGTETA, respectively. Cluster analysis using molecular data and UPGMA algorithm, classified the studied genotypes in three distinguished groups. The genotypes at the same geographical region did not classify in the same group based on clustering by molecular data. However, this achieved to a large extent when they were classified groups using morphological traits. This result might be explained in terms of convergent evolution and some in part due to asexual propagation of Russian olive from the limited maternal genotypes and distribution across the different geographical regions.
\end{abstract}

Keywords: Genetic diversity, Elaeagnus angustifolia, Quantitative traits, AFLP

\footnotetext{
* Corresponding Author, E-mail: asoleimani@znu.ac.ir

\# These authors contributed equally to this work
} 